\title{
Unilateral complex partial denture performance evaluation: 5 years follow up clinical study
}

\author{
Katarina Radović1, Rade Živković ${ }^{1}$, Jovana Kuzmanovic Pficer² ${ }^{2}$ Ljiljana Tihaček Šojić1, \\ Aleksandra Milić Lemić \\ ${ }^{1}$ University of Belgrade, School of Dental Medicine, Department for Prosthodontics, Belgrade, Serbia; \\ ${ }^{2}$ University of Belgrade, School of Dental Medicine, Department for Biostatistics and Informatics, Belgrade, Serbia
}

\begin{abstract}
SUMMARY
Introduction Removable partial denture (RPD) is common treatment option for unilateral partially edentulous patients not indicated for implant therapy. Unilateral complex partial denture (UCPD) could be an alternative approach to RPD treatment, but there is lack of evidence about UCPD treatment outcomes during the long-term clinical performance. The aim of this this study was to use periodontal, prosthodontic and participant satisfaction measures to evaluate the long-term clinical performance of UCPD.

Material and methods This 5 year follow-up clinical study evaluated pocket probing depth (PPD) and vertical clinical attachment loss (CAL-V) of direct abutment (DA), indirect abutment (IA) and control teeth (CT). Also complications and failures of UCPD were analysed using questionnaire of participant satisfaction with UCPD (stability, comfort and manipulation).

Results Evaluation of data showed that CAL-V and PPD significantly increased over time for DA, IA and CT $(p<0.0001)$, but the tooth function (DA, IA and CT) did not significantly influence changes in PPD and CAL-V. The fracture of one abutment tooth and increase of the number of artificial teeth deformations $(p=0.039)$ were observed after 5 years. Participant satisfaction with denture after 1 year and 5 years vs. 7 days was significantly improved.

Conclusion Despite limitations of this clinical study and assuming regular oral maintenance with proper indication, UCPD might be considered as good treatment option for Kennedy II rehabilitation in patients not indicated for implant therapy or who cannot tolerate extensive RPD design.

Keywords: denture complications and failures; periodontal parameters; participants' satisfaction; unilateral complex partial denture
\end{abstract}

\section{INTRODUCTION}

Oral rehabilitation of unilaterally shortened dental arch includes removable, fixed and implant borne restorations $[1,2,3]$. Removable partial denture (RPD) is still common treatment option for unilateral partially edentulous patients who can't be candidates for an implant treatment due to various reasons including lack of bone support with anatomical limitations such as position of maxillary sinus, inferior alveolar nerve and health condition. Evidence has shown satisfactory clinical results with clasp-retained RPDs concerning survival and extraction rate of abutment teeth $[4,5]$, but aesthetic outcomes for clasp-retained RPDs in comparison to precision attachment retained RPDs were low [6]. To enable proper assessment of the oral needs and treatment demands of dental patients with adequate prediction of therapeutic interventions outcomes, it is important to recognize patients' self-perception of quality of life in terms of oral-health. Namely, the presence of denture plate as a part of RPD might cause the so-called foreign body sensation and nausea whereas clasps often do not meet patients aesthetic and comfort needs $[7,8]$. To overcome those problems, unilateral complex partial denture (UCPD) without denture palate retained with latch type of attachment could be an optional treatment for unilaterally partially edentulous patients (Kennedy class II). However, the use of UCPD in dental practice might be a controversial subject, having in mind possibility of overloading abutment teeth and lack of major connector with contributing factor in denture retention. Hence, to date there have been few clinical reports concerning UCPD, while the actual impact of UCPD on oral health is not clarified yet.

The aim of this study was to use periodontal, prosthodontic and participant satisfaction measures to evaluate the long-term clinical performance of UCPD with a snap in latch attachment.

\section{MATERIAL AND METHODS}

\section{Participants}

This study design and data collection methods were approved by the Ethics Committee of the School of Dental Medicine, University of Belgrade, Serbia (No: 36/26). 
Fourteen participants provided informed consent forms in accordance with the World Medical Association Declaration of Helsinki, and participated in the study (10 men and 4 women; age range: 57 to 68 years). The predefined inclusion criteria were: participants were maxillary unilaterally partially edentulous (Kennedy class II) with missing second premolar and first and second molars; not indicated for implant treatment due to lack of bone and position of maxillary sinus; refused denture with palatal plate and therefore indicated for UCPD; and available for periodic checkups every 6 months up to 5 years. Since 3 patients didn't maintain oral hygiene properly and didn't come to the clinic for regular check-ups, they were excluded from the study. Also, one patient refused to use his denture for the reason of discomfort caused by the pin of latch attachment. The final number of participants enrolled in the study was 10 .

\section{Interventions}

The design of UCPD considered precision attachment retained restoration (SD snap in latch attachment, ServoDental GmbH \& Co. KG, Hagen, Germany) consisting of free-end denture saddle attached to splinted 2 abutment teeth, canine and first premolar covered with milled crowns due to the absence of major connector. The primary part of attachment made of fully combustible plastic was integrated in a milled crown on the abutment tooth and casted together with crowns. The secondary component of attachment made of titanium was adhered into unilateral saddle and created the latch type connection of the whole restoration.

Preprosthetic procedure included the following periodontal treatment: motivation for oral hygiene; instruction in oral hygiene procedures with adequate oral hygiene manual; scaling, root planning and polishing.

The procedures for making UCPD included teeth preparation, taking impression for crowns using addition polymerization silicone material (Elite HD+, Zhermack, Italy) and try-in phase of metal framework that involved primary part of attachment and try-in ceramic. The impression for unilateral metal framework of saddle was made with the crowns placed on teeth. After casting metal framework for free-end saddle, it was evaluated intraorally. The following phases included the placement of secondary component of attachment and adhering into metal framework. Glazed crowns and finished UCPD with maximally extended free-end saddle were attached together and placed in mouth. The crowns were cemented according to standard procedures for cementing milled crowns with attachments. The participants were instructed how to use and maintain denture and additionally educated and motivated to perform appropriate oral hygiene protocols.

The patients were asked to visit the clinic every 6 months for regular check-ups. During the appointments they were re-motivated to maintain oral hygiene of the teeth and appliance.

\section{Outcomes}

After denture insertion, during the appointments after 7 days, 1 year and 5 years, trained and calibrated external examiners (in most cases in the presence of treatment coordinator) measured periodontal indices, recorded prosthetic parameters and completed the questionnaire of participant satisfaction with UCPD during the study.

\section{Periodontal outcomes}

Teeth were classified according to their relation to the attachment and free-end saddle and divided into the three groups: direct abutment (first premolar), indirect abutment (canine) and control teeth (same tooth on the opposing side of the jaw). Periodontal conditions of direct abutment (DA), indirect abutment (IA) and control teeth (CT) were evaluated using pocket probing depth (PPD) and vertical clinical attachment loss (CAL-V). The measurements of PPD and CAL-V were conducted with graduated periodontal probe at 6 sites per tooth (buccal, distal-buccal, mesial-buccal, lingual, mesial-lingual and distal-lingual). CAL-V was measured from the crown margin.

\section{Prosthetic Outcomes}

At every recall, abutment teeth and UCPD were evaluated for complications according to slightly modified standard criteria for complications and failures of RPD presented by Saito et al. [9].

1. Teeth

Fracture and/or missing teeth: yes or no

2. Attachment

Fracture and /or deformation: yes or no

3. Denture base

Fracture and /or deformation: yes or no

4. Artificial teeth

Fracture and /or deformation of acrylic veneering: yes or no

\section{Participants' satisfaction}

The participants were asked to complete a questionnaire regarding the stability, comfort and difficulties in denture manipulation based on verbal rating scale (VRS), ranging from 1 to $5(1=$ completely unsatisfied; $5=$ completely satisfied $)$.

\section{Statistical methods}

All statistical analyses were performed using Statistical Package for Social Science (SPSS software package, version 18.0; SPSS Inc., Chicago, IL, USA). Mean, median, $\mathrm{SD}$ and range were used for descriptive data. Category variables were compared using Cochran test. Non-parametric data were analysed using Friedman and Wilcoxon test. The mixed between-within subject ANOVA was used to show the interaction of time and type of abutments. Inter-group comparisons were analysed using one-way analysis of variance (ANOVA). P value less than 0.05 was considered statistically significant. 


\section{RESULTS}

The influence of three abutments (direct abutment, indirect abutment or control) on CAL-V changes during the observation period ( 7 days, 1 year, 5 years) is shown in Figure 1. The results showed that CAL-V significantly increased over time for all observed teeth $(\mathrm{p}<0.0001)$, but interaction between groups for each parameter did not show significant difference. Inter-group comparison did not show statistically significant differences between abutment teeth for each time separately.

Figure 2 shows PPD changes during the evaluation period ( 7 days, 1 year, 5 years) for each observed group of teeth (direct abutment, indirect abutment or control). PPD significantly increased in all observed groups over time ( $<<0.0001)$, but the results did not show statistically significant interactions between tooth function and time. The results also showed that the tooth function (direct abutment, indirect abutment or control) did not significantly influence the changes in PPD for each time separately.

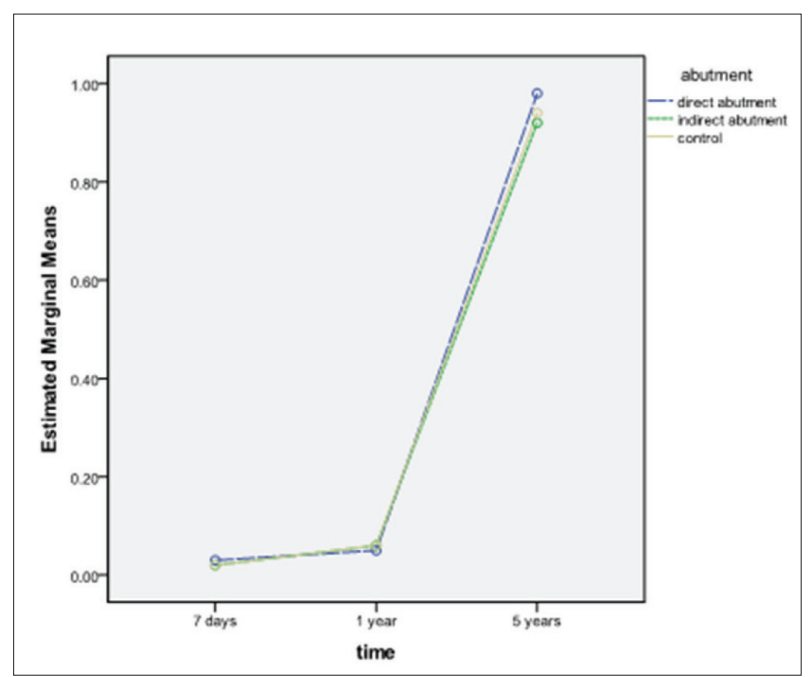

Figure 1. Abutment teeth influence on CAL-V over time Slika 1. Uticaj zuba nosača na CAL/V tokom vremena

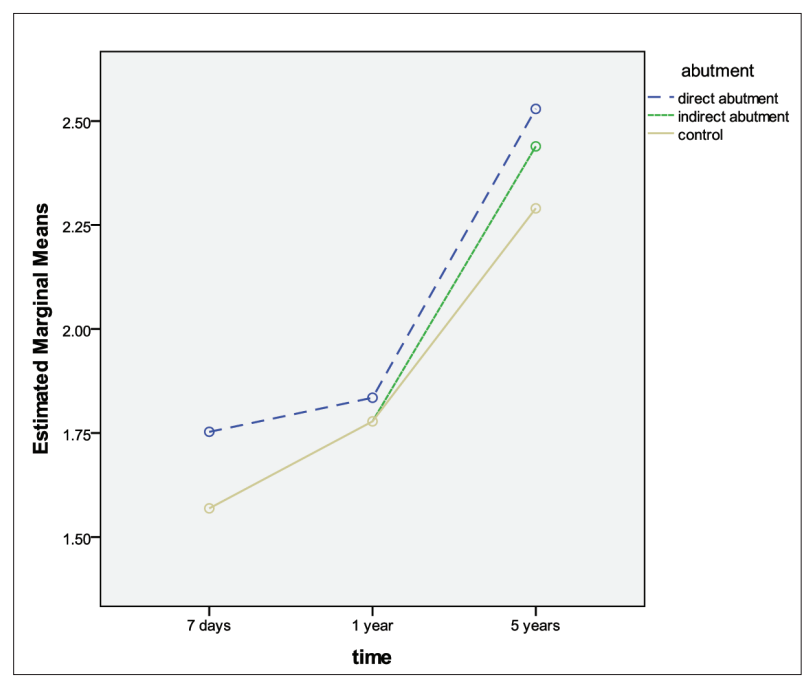

Figure 2. Abutment teeth influence on PPD over time Slika 2. Uticaj zuba nosača na PPD tokom vremena
The incidence of prosthetic complications and denture failures are shown in Table 1. The results showed the fracture of one abutment tooth and deformation of one retainer after 5 years of wearing UCPD, but compared to data after 7 days and 1 year it was without statistical significance. On the contrary, the number of artificial teeth deformation was significantly increased over time $(p=0,039)$. During the evaluation period, denture base deformation was not identified.

Table 1. Incidence of complications and failures

Tabela 1. Učestalost komplikacija i neuspeha

\begin{tabular}{|c|c|c|c|}
\hline \multirow{2}{*}{$\begin{array}{l}\text { Complications and } \\
\text { failures (number) } \\
\text { Komplikacija i neuspeh } \\
\text { (broj) }\end{array}$} & \multicolumn{3}{|c|}{$\begin{array}{l}\text { Evaluation period } \\
\text { Period evaluacije }\end{array}$} \\
\hline & $\begin{array}{l}\text { After } 7 \text { days } \\
\text { Posle } 7 \text { dana }\end{array}$ & $\begin{array}{l}\text { After } 1 \text { year } \\
\text { Posle } \\
\text { godinu dana }\end{array}$ & $\begin{array}{c}\text { After } 5 \\
\text { years } \\
\text { Posle } 5 \\
\text { godina }\end{array}$ \\
\hline $\begin{array}{l}\text { Tooth fracture } \\
\text { Prelom zuba }\end{array}$ & 0 & 0 & 1 \\
\hline $\begin{array}{l}\text { Retainer deformation } \\
\text { Deformacija nosača }\end{array}$ & 0 & 0 & 1 \\
\hline $\begin{array}{l}\text { Denture base deformation } \\
\text { Deformacija baze proteze }\end{array}$ & 0 & 0 & 0 \\
\hline $\begin{array}{l}\text { Fracture of acrilic veneering } \\
\text { Prelom akrilne fasete }\end{array}$ & 0 & 1 & $4^{*} 1$ \\
\hline
\end{tabular}

Table 2 shows participant satisfaction with denture stability, comfort and manipulation. The results showed that all three parameters were significantly improved after 1 year and after 5 years period of denture wearing compared to the data after 7 days of denture insertion. It is evident that maximum score was given for denture stability for all evaluation periods, while patients' satisfaction after 7 days was assigned number 3 on the scale from 1 to 5. During subsequent periods of evaluation comfort and manipulation parameters achieved higher scores.

\section{DISCUSSION}

Despite various clinical options offered by dental implants, therapy with RPD is still the most common treatment option in partially edentulous patients without posterior teeth [10]. Therefore, it is very important to assess treatment outcomes with RPD considering the preservation of supporting tissues and teeth and patients' comfort and aesthetic demands. Based on our evidence, there have been only few clinical studies investigating UCPD $[11,12]$, which is considered to be a restoration with high functional and aesthetic values.

The results of our study showed that UCPD wearers reported high scores for all 3 measured prosthetic satisfaction parameters: stability, comfort and manipulation during the appointments after 7 days, 1 year and 5 years. Taking into account the lack of literature related to UCPD and if UCPD is compared to CFPD as a restoration also characterized by attached pontics, the result of this study is in compliance with the evidence estimating that lack of palatal base in CFPD gives advantages to RPD regard- 
Table 2. Participant satisfaction with denture Tabela 2. Pacijentovo zadovoljstvo protezom

\begin{tabular}{|c|c|c|c|c|c|}
\hline \multirow{2}{*}{$\begin{array}{l}\text { Prosthetic parametres } \\
\text { Protetički } \\
\text { parametri }\end{array}$} & \multicolumn{3}{|c|}{$\begin{array}{l}\text { Evaluation period } \\
\text { Period evaluacije }\end{array}$} & \multirow{2}{*}{\multicolumn{2}{|c|}{$\begin{array}{c}p \text { value } \\
\text { vrednost } p\end{array}$}} \\
\hline & $\begin{array}{c}\text { After } 7 \text { days } \\
\text { Posle } 7 \text { dana (min.-max.) } \\
\text { Md }\end{array}$ & $\begin{array}{c}\text { After } 1 \text { year } \\
\text { Posle godinu dana (min.-max.) } \\
\text { Md }\end{array}$ & $\begin{array}{c}\text { After } 1 \text { year } \\
\text { Posle } 5 \text { godina (min.-max.) } \\
\text { Md }\end{array}$ & & \\
\hline $\begin{array}{l}\text { Denture stability } \\
\text { Stabilnost proteze }\end{array}$ & $4(3-5)$ & $5(4-5)$ & $5(4-5)$ & $\mathrm{p}=0.018^{*} 1$ & $\begin{array}{l}\text { 7vs1y, } p=0.025^{*} 2 \\
\text { 7vs5yrs, } p=0.034^{*} \\
\text { 1yvs 5yrs, } p=0.564\end{array}$ \\
\hline $\begin{array}{l}\text { Comfort } \\
\text { Komfor }\end{array}$ & $3(2-4)$ & $5(4-5)$ & $5(4-5)$ & $\mathrm{p}=0.001^{*} 1$ & $\begin{array}{l}\text { 7vs1y, } p=0.007^{*} 2 \\
\text { 7vs 5yrs, } p=0.007^{*} \\
\text { 1yvs 5yrs } p=0.317\end{array}$ \\
\hline $\begin{array}{l}\text { Manipulation } \\
\text { Manipulacija }\end{array}$ & $3(2-4)$ & $5(4-5)$ & $5(4-5)$ & $\mathrm{p}=0.002^{*} 1$ & $\begin{array}{l}\text { 7vs1y } p=0.010^{*} 2 \\
\text { 7vs5yrs, } p=0.010^{*} \\
\text { 1yvs5yrs, } p=0.317\end{array}$ \\
\hline
\end{tabular}

Md - Median; ${ }^{*}$ - statistically significant; ${ }^{1}$ - Friedman test; ${ }^{2}$ - Wilcoxon test

Md - Mediana; ${ }^{*}$ - statistički značajno; ${ }^{1}-$ Fridmanov test; ${ }^{2}-$ Vilkinsonov test

ing patient comfort and satisfaction [12]. Interestingly, the results of the present study also showed that patients' satisfaction with UCPD significantly increased over time. One may speculate that the period of 7 days was not long enough for complete patient adaptation and that was the reason for significantly lower scores for stability, comfort and manipulation after 7 days in comparison to the scores after 1 and 5 years. As the time passed the patients got used to the appliance with evident increase of the comfort and manipulation.

The overload of abutment teeth for restorations without palatal plate and attached pontics is a controversial question. The results of the present study showed fracture of one abutment tooth after 5 years of UCPD function. This is in accordance with the findings of Schmitt et al. who performed 5 -year follow up study comparing unilateral and bilateral dentures retained by miniaturized attachment system [13]. According to their findings, in contrast to unilaterally retained removable dentures where splinted abutment teeth had high survival rate, fracture of abutment teeth was the most common complication and cause for failure of bilateral partial dentures (with non-splinted abutment teeth). The findings of our study are also in accordance with the finite element method (FEM) analyses of UCPD [14]. Namely, comparing the UCPD and RPD through FME stress analysis, calculations showed that applied forces are within physiological limits on splinted direct and indirect abutments of UCPD (canine and first premolar), which behaviour was similar to the behaviour of direct abutment of conventional RPD.

The results regarding the technical complications showed reparable deformation of the sprue in one latch attachment after 5 years of wearing UCPD, in contrast to the results of Schmitt et al. [13] who reported high rate of irreversible mechanical wear of male part of used attachment after 4 years of clinical function with the need for restoration replacement. According to these findings, latch attachment with sprue might be more suitable for unilateral free end saddle treatment in comparison to miniaturized attachment system. Also, type of attachment offers denture stability in unilateral cases and mouth safety, since removal is not possible unless the aforementioned button is pressed and denture is deliberately displaced. A fracture of acrylic veneering present in our patients was also common complication similar to findings of Schmitt et al. [13]

Due to the fact that primary causes of denture abutment teeth failures are periodontal disease and caries $[15,16]$, periodontal status of abutment teeth involved in UCPD restoration was evaluated. The results of UCPD clinical prognosis through evaluation of periodontal status of direct and indirect abutment teeth and control teeth in the opposite side of the same jaw showed that PPD and CAL-V significantly increased for all observed groups over time. However, PPD and CAL-V values of direct abutment and indirect abutment teeth were not significantly different from control teeth that were not involved in UCPD. Therefore, we might estimate that teeth splinting increases load potential despite the presence of palatal base and latch attachment providing elastic connection between fixed and maximally extended free-end saddle. As mentioned by Jorge et al. [17] such favorable results could be attributed to well planned prosthetic treatment and properly designed removable partial dentures.

It's interesting to mention that follow-up clinical studies of RPD showed controversial findings regarding the influence of tooth function (direct abutment, indirect abutment or control) on periodontal attachment loss. Contrary to findings showing that tooth function significantly influences gingival recession and probing depth $[18,19]$, Drake and Beck [20] did not find difference in PPD between patients wearing RPDs and not wearing RPDs. In accordance with this, Schmitt et al. [13] even identified improvement in periodontal parameters for abutments of unilateral denture compared to the baseline values suggesting that restoration is reliable treatment modality for periodontal health.

For better prediction of clinical performance of unilateral complex partial denture it is necessary however to enrol more participants for longer evaluation time, because the main limitation of this study was the small sample size and therefore it might be considered as preliminary study. Although the sample size was small, its distribution was in accordance with previous studies $[21,22]$. 


\section{CONCLUSION}

Despite the limitations of this clinical study and with assuming regular oral hygiene maintenance with proper indication conditions, UCPD might be good treatment option in Kennedy II rehabilitation for patients not indicated for implant therapy or who cannot tolerate extensive RPD design. Good clinical performance indicators were observed over time and patients reported adequate satisfaction, comfort and suitable manipulation.

\section{REFERENCES}

1. McKenna G, Allen PF, O'Mahony D, Cronin M, DaMata C, Woods $\mathrm{N}$. The impact of rehabilitation using removable partial dentures and functionally orientated treatment on oral health-related quality of life: a randomised controlled clinical trial. J Dent. 2015; 43(1):66-71. [DOI: 10.1016/j.jdent.2014.06.006] [PMID: 24973731]

2. Wolfart S, Müller F, Gerß J, Heyedcke G, Marré B, Böning K, et al. The randomized shortened dental arch study: oral health-related quality of life. Clin Oral Investig. 2014; 18(2):525-33. [DOI: 10.1007/ s00784-013-0991-6] [PMID: 23680969]

3. Pjetursson BE, Tan K, Lang NP, Brägger U, Egger $M$, Zwahlen $M$. A systematic review of the survival and complication rates of fixed partial dentures (FPDs) after an observation period of at least 5 years. Clin Oral Implants Res. 2004; 15(6):667-76. [DOl: 10.1111/j.1600-0501.2004.01120.x] [PMID: 15533127]

4. Rehmann P, Orbach K, Ferger P, Wöstmann B. Treatment outcomes with removable partial dentures: a retrospective analysis. Int J Prosthodont. 2013; 26(2):147-50. [DOI: 10.11607/ijp.2959] [PMID: 23476909].

5. Behr M, Zeman F, Passauer T, Koller M, Hahnel S, Buergers R, et al. Clinical performance of cast clasp-retained removable partial dentures: a retrospective study. Int J Prosthodont. 2012; 25(2):138-44. [PMID: 22371834]

6. Peršić S, Kranjčić J, Pavičić DK, Mikić VL, Čelebić A. Treatment outcomes based on patients' self-reported measures after receiving new clasp or precision attachment-retained removable partial dentures. J Prosthodont. 2017; 26(2):115-22. [DOl: 10.1111/jopr.12395] [PMID: 26618630]

7. Inukai M, Baba K, John MT, Igarashi Y. Does removable partial denture quality affect individuals' oral health? J Dent Res. 2008; 87(8):736-9. [DOI: 10.1177/154405910808700816] [PMID: 18650544]

8. Koyama S, Sasaki K, Kawata T, Atsumi T, Watanabe M. Multivariate analysis of patient satisfaction factors affecting the usage of removable partial dentures. Int J Prosthodont. 2008; 21(6):499-500. [PMID: 19149065]

9. Saito M, Notani K, Miura Y, Kawasaki T. Complications and failures in removable partial dentures: a clinical evaluation. J Oral Rehabil. 2002; 29(7):627-33. [DOI: 10.1046/j.1365-2842.2002.00898.x] [PMID: 12153451]
10. Tanasić IV, Tihacek-Sojić LĐ, Milić-Lemić AM. Prevalence and clinical effects of certain therapy concepts among partially edentulous Serbian elderly. J Prosthodont. 2015; 24(8):610-4. [DOI: 10.1111/ jopr.12261] [PMID: 25594777]

11. Barker D, Cooper A. A novel use of a unilateral hinged partial denture. Br Dent J. 2006; 201(9):571-3. [DOI: 10.1038/sj.bdj.4814207] [PMID: 17099662]

12. Budtz-Jørgensen E, Isidor F. A 5-year longitudinal study of cantilevered fixed partial dentures compared with removable partial dentures in a geriatric population. J Prosthet Dent. 1990; 64(1):427. [DOI: 10.1038/sj.bdj.4814207] [PMID: 17099662]

13. Schmitt J, Wichmann M, Eitner S, Hamel J, Holst S. Five-year clinical follow-up of prefabricated precision attachments: a comparison of uni- and bilateral removable dental prostheses. Quintessence Int. 2011; 42(5):413-8. [PMID: 21519561]

14. Radović K, Čairović A, Todorović A, Stančić I, Grbović A. Comparative analysis of unilateral removable partial denture and classical removable partial denture by using finite element method]. Srp Arh Celok Lek. 2010; 138:706-13. [DOI: 10.2298/SARH1012706R] [PMID: 21365883]

15. Wagner B, Kern M. Clinical evaluation of removable partial dentures 10 years after insertion: success rates, hygienic problems, and technical failures. Clin Oral Investig. 2000; 4(2):74-80. [DOI: 10.1007/s007840050119] [PMID: 11218504]

16. Kern $M$, Wagner B. Periodontal findings in patients 10 years after insertion of removable partial dentures. J Oral Rehabil. 2001; 28(11):99-7. [DOI: 10.1111/j.1365-2842.2001.00788.x] [PMID: 11722713]

17. Jorge JH, Quishida CC, Vergani CE, Machado AL, Pavarina AC, Giampaolo ET. Clinical evaluation of failures in removable partial dentures. J Oral Sci. 2012; 54(4):337-42. [DOI: 10.2334/josnusd.54.337] [PMID: 23221159]

18. da Fonte Porto Carreiro A, de Carvalho Dias K, Correia Lopes AL, Bastos Machado Resende CM, Luz de Aquino Martins AR. Periodontal conditions of abutments and non-abutments in removable partial dentures over 7 years of use. J Prosthodont. 2017; 26(8):644-9. [DOI: 10.1111/jopr.12449] [PMID: 26864601]

19. Zlatarić DK, Celebić A, Valentić-Peruzović M. The effect of removable partial dentures on periodontal health of abutment and nonabutment teeth. J Periodontol. 2002; 73(2):137-44. [DOI: 10.1902/ jop.2002.73.2.137] [PMID: 11895277]

20. Drake CW, Beck JD. The oral status of elderly removable partial denture wearers. J Oral Rehabil. 1993; 20(1):53-60. [DOI: 10.1111/ j.1365-2842.1993.tb01514.x] [PMID: 8429423]

21. Yang TC, Maeda Y, Gonda T. Clinical performance and satisfaction of removable prostheses with self-adjusting magnetic attachments.J Prosthet Dent. 2014; 111:131-5. [DOI: 10.1016/j.prosdent.2013.07.001] [PMID: 24210730]

22. Shimura Y, Wadachi J, Nakamura T, Mizutani H, Igarashi Y. Influence of removable partial dentures on the formation of dental plaque on abutment teeth. J Prosth Res. 2010; 54:29-35. [DOI: 10.1016/j.jpor.2009.08.003] [PMID: 19818702]

Received: 04.05.2018 • Accepted: Prihvaćen 13.08.2018 


\title{
Procena uspešnosti terapije jednostranom kompleksnom skeletiranom parcijalnom protezom: petogodišnja klinička studija
}

\author{
Katarina Radović1, Rade Živković1, Jovana Kuzmanovic Pficer², Ljiljana Tihaček Šojićn, Aleksandra Milić \\ Lemić $^{1}$ \\ 'Univerzitet u Beogradu, Stomatološki fakultet, Klinika za stomatološku protetiku, Beograd, Srbija; \\ ${ }^{2}$ Univerzitet u Beogradu, Stomatološki fakultet, Departman za biostatistiku i informatiku, Beograd, Srbija
}

\begin{abstract}
KRATAK SADRŽAJ
Uvod Parcijalna skeletirana proteza (PSP) najčešća je terapijska opcija kod jednostrane krezubosti kada nije indikovana implantološka terapija. Jednostrana kompleksna parcijalna skeletirana proteza (JKPSP) predstavlja alternativu konvencionalnoj PSP, jedino što ne postoje evidentni podaci o uspešnosti terapije nakon duže kliničke upotrebe.

Cilj ovog rada bio je da se na osnovu analize objektivnih pokazatelja, odnosno analize periodontalnih i protetskih parametara, kao i na osnovu subjektivnih ocena pacijenta, izvrši provera uspešnosti JKPSP retiniranim atečmenom tipa reze sa oprugom nakon petogodišnjeg praćenja.

Materijal i metod Kod deset ispitanika oba pola izvršeno je praćenje gubitka vertikalnog pripoja gingive i dubine parodontalnih džepova, kod primarnog retencionog zuba (PRZ), sekundarnog retencionog zuba (SRZ), koji su bili u sastavu JKPSP i kontrolnog zuba (KZ) suprotne strane vilice. Takođe, analizirani su protetske komplikacije (fraktura zuba, gubitak veštačkih zuba) i zadovoljstvo pacijenata na osnovu popunjenih upitnika, gde su oni ocenjivali stabilnost, komfor i rukovanje JKPSP.

Rezultati Nakon analize dobijnih podataka uočeno je da se vrednost dubine parodontalnih džepova i gubitak vertikalnog pripoja gingive kod PRZ statistički značajno razlikuju u odnosu na SRZ i KZ ( $p<0,0001)$. Zabeležene protetske komplikacije u vidu frakture retencionog zuba i deformacije veštačkih akrilatnih zuba nisu bile statistički značajne posle pet godina praćenja. Zadovoljstvo pacijenata JKPSP posle prve godine i posle pet godina nošenja se značajno popravilo u odnosu na prvih sedam dana posle predaje. Zaključak Nezavisno od ograničenja ove kliničke studije, uzimajući u obzir adekvatnu indikaciju i pravilno održavanje higijene, JKPSP se može smatrati dobrom opcijom za rehabilitaciju krezubosti Kenedi Il klase kod pacijenata kod kojih nije indikovana terapija implantatima, odnosno koji ne prihvataju prisustvo velike spojnice. Pacijenti su bili zadovoljni protezama, njihovim komforom i lakoćom rukovanja protezama.

Ključne reči: protetske komplikacije; periodontalni parametri; zadovoljstvo pacijenata; jednostrana kompleksna parcijalna skeletirana proteza
\end{abstract}

\section{UVOD}

Protetska rehabilitacija jednostrano skraćenog zubnog niza podrazumeva izradu parcijalnih proteza, fiksnih nadoknada odnosno krilnih mostova i implantatno nošenih nadoknada $[1,2,3]$. Parcijalna skeletirana proteza (PSP) još je uvek veoma česta opcija za rehabilitaciju jednostranog skraćenog zubnog niza, pogovoto kod pacijenata koji nisu kandidati za ugradnju implantata, bilo usled anatomskih ili ekonomskih ograničenja, ili usled sistemskih bolesti. Razmatrajući kliničke rezultate postignute kod nosilaca konvencionalnih PSP, neosporni su zadovoljavajući efekti koji se tiču preživljavanja i očuvanja retencionih zuba $[4,5]$. Međutim, estetski rezultati konvencionalnih PSP u poređenju sa kompleksnim PSP retiniranim preciznim veznim elementima veoma su loši [6]. Na osnovu navedenog može se reći da su pravilna procena pacijentovih potreba i adekvatno predviđanje uspešnosti protetske terapije od velikog značaja kako bi se uticalo na kvalitet oralnog zdravlja i zadovoljstvo pacijenta. U vezi sa tim, značajno je naglasiti da prisustvo velike spojnice PSP na nepcu uslovljava senzacije stranog tela, a u ekstremnim slučajevima mučninu, čime je umanjena komfornost pacijenta, dok metalne kukice ne zadovoljavaju estetske zahteve $[7,8]$. Za prevazilaženje navedenih problema jednostrana kompleksna parcijalna skeletirana proteza (JKPSP) bez velike spojnice retinirana atečmenom tipa reze može biti uspešan terapeutski modalitet za rehabilitaciju pacijenata klase krezubosti Kenedi II. Međutim, primena JKPSP u stomatološkoj praksi nije u potpunosti prihvaćena, posebno kada se uzmu u obzir mogućnosti preopterećenja retencionih zuba i nedostatka velike spojnice i njenog učešća u stabilizaciji proteze. Uvidom u postojeću literaturu nisu uočeni klinički podaci koji se tiču uspešnosti terapije JKPSP, posebno kada se uzme u obzir njen uticaj na oralno zdravlje pacijenta nosioca.

Cilj ovog rada bio je da se na osnovu analize objektivnih pokazatelja, odnosno analize periodontalnih i protetskih parametara, kao i na osnovu subjektivnih ocena pacijenta, izvrši provera uspešnosti JKPSP retiniranim atečmenom tipa reze sa oprugom nakon petogodišnjeg praćenja.

\section{MATERIJAL I METOD}

\section{Učesnici studije}

Dizajn studije i prikupljanje podataka odobreni su od strane Etičkog komiteta Stomatološkog fakulteta Univerziteta u Beogradu (Br: 36/26). Četrnaest učesnika studije je dalo svoj pisani pristanak u skladu sa Helsinškom dekalaracijom za učestvovanje u studiji (10 muškaraca i četiri žene, starosti od 57 do 68 godina). Definisani kriterijumi za učešće u studiji bili su i) jednostrana krezubost u gornjoj vilici (klase Kenedi II) sa nedostajućim zubima: drugi premolar i prvi i drugi molari; ii) nemogućnost ugradnje implantata usled anatomskih ili ekonomskih ograničenja; iii) odbijanje da nose PSP sa velikom spojnicom preko nepca. Nakon petogodišnjeg praćenja pacijenata, troje nije održavalo odgovarajući nivo oralne higijene i nisu poštovali 
dolaske na redovne kontrole, dok je jedan pacijent odbio da nosi JKPSP usled nekomfornosti usled prisustva atečmena. Konačan broj učesnika bio je 10 .

\section{Protetski postupci}

Dizajn JKPSP podrazumevao je jednostrano slobodno sedlo, bez prisustva velike spojnice, koji je preciznim veznim elementom (SD snap in latch attachment, Servo-Dental GmbH \& Co. KG, Hagen, Germany) povezan sa frezovanim krunama na retencionim zubima - očnjaku i prvom premolaru. Patrica atečmena napravljena od plastike bila je livena zajedno sa frezovanim krunama koje su cementirane na retencione zube. Titanijumska matrica atečmena bila je sastavni deo jednostranog sedla i zajedno sa oprugom i dugmetom za stavljanje i skidanje proteze predstavljala vezu tipa reze za celu konstrukciju. Preprotetska priprema podrazumevala je odgovarajuću parodontalnu pripremu kod nadležnog specijaliste: motivaciju za održavanje oralne higijene, instrukcije o sredstvima i postupcima za održavanje oralne higijene, uklanjanje mekih i čvrstih naslaga.

Postupci u okviru protetske rehabilitacije podrazumevali su: preparaciju retencionih zuba, otiskivanje zuba za fiksne nadoknade adicionim silikonom (Elite HD+, Zhermack, Italy), probu metalne konstrukcije sa primarnim delom atečmena i probu keramike. Otiskivanje za metalni deo JKPSP je obavljeno preko kruna postavljenih na retencione zube. Sledeći postupak podrazumevao je probu skeleta JKPSP, zatim postavljanje sekundarnog dela atečmena. Glazirane namenske krune su cementirane zajedno sa postavljenom JKPSP i u istom aktu predate pacijentima. Pacijenti su obučeni o načinu održavanja oralne higijene i dodatno motivisani kako bi poštovali odgovarajući protokol održavanja higijene usled prisustva atečmena.

\section{Objektivni i subjektivni pokazatelji}

Nakon predaje JKPSP evaluacija objektivnih parametara je izvršena posle prvih sedam dana, prve godine i pete godine. Obučeni specijalista stomatološke protetike je izvršio merenja parodontalnih parametara, evaluirao protetske parametre $\mathrm{i}$ sproveo popunjavanje upitnika o subjektivnom zadovoljstvu pacijenata JKPSP.

\section{Parodontalni parametri}

Retencioni zubi su u odnosu na položaj prema slobodnom sedlu i prema atečmenu podeljeni na tri grupe: direktni retencioni zub (prvi premolar), indirektni retencioni zub (očnjak) i kontrolni zubi (zubi iste klase na suprotnoj strani vilice). Parodontalni parametri mereni su na direktnim retencionim zubima (DRZ), indirektnim retencionim zubima (IRZ) i kontrolnim zubima (KZ) i to dubinom parodontalnog džepa (PPD) i gubitkom vertikalnog pripoja gingive. Merenja pomenutih parametara izvršena su pomoću graduisane parodontalne sonde na šest strana svakog pomenutog zuba (bukalno, disto-bukalno, mezio-bukalno, lingvalno, mezio-lingvalno i disto-lingvalno), dok je gubitak vertikalnog pripoja gingive meren od ivice krune.

\section{Protetski parametri}

Protetske komplikacije su sprovođene prema nešto izmenjenim kriterijumima za komplikacije i greške kod PSP koje su predložili Saito i sar. [9].

1. Zubi

Prelom i/ili gubitak zuba: da ili ne

2. Atečmen

Prelom i/ili deformacija: da ili ne

3. Skelet proteze

Prelom i/ili deformacija: da ili ne

4. Veštački zubi

4 Fraktura i/ili deformacija akrilatne fasete: da ili ne

\section{Zadovoljstvo pacijenta}

Učesnici studije su popunjavali upitnike odgovarajući na pitanja koja se tiču stabilizacije, udobnosti i poteškoća tokom manipulisanja JKPSP-om. Ocene su bile u rasponu od 1 do 5 na vizuelno-analognoj skali (VAS), gde je 1 značilo potpuno nezadovoljan, a 5 potpuno zadovoljan.

\section{Statistička analiza}

Sve statističke analize su izvršene pomoću programa SPSS (SPSS software package, version 18.0; SPSS Inc., Chicago, IL, USA). Srednja vrednost, medijana, standardna devijacija i raspon su korišćeni za opisivanje podataka. Varijable kategorije su poređene pomoću Kohranovog testa (Cochran test). Neparametrijske analize su izvršene pomoću Fridman i Vilkokson testa (Friedman $i$ Wilcoxon test). ANOVA je korišćena da se prikaže uticaj vremena na promene na retencionim zubima, dok je međugrupna komparacija izvršena analizom varijanse (ANOVA). Za statisitčku značajnost je uzeto da je P vrednost manja od 0,05.

\section{REZULTATI}

Na Grafikonu 1 prikazan je gubitak vertikalnog pripoja gingive $(\mathrm{CAL}-\mathrm{V})$ na direktnom retencionom zubu (prvi premolar), indirektnom retencionim zubu (očnjak) i kontrolnim zubima (zubi iste klase na suprotnoj strani vilice) evaluacijom nakon sedam dana, prve i pete godine. Rezultati su pokazali da je značajno povećan gubitak vertikalnog pripoja gingive na svim posmatranim zubima $(\mathrm{p}<0,0001)$, ali bez statistički značajne razlike. Komparacija između grupa takođe nije pokazala statistički značajne razlike u pojedinačnim terminima evaluacije.

Na Grafikonu 2 prikazane su vrednosti za dubinu parodontalnog džepa (PPD) u terminima evaluacije (sedam dana, prve i pete godine) za svaku posmatranu grupu zuba (DRZ, IRZ, $\mathrm{KZ}$ ). Dubina parodontalnih džepova značajno je povećana za sve posmatrane grupe tokom vremena $(\mathrm{p}<0,0001)$, ali rezultati nisu pokazali statistički značajnu interakciju između funkcije zuba i vremena. Rezultati su takođe pokazali da funkcija zuba u odnosu na to da li je direktni, indirektni retencioni zub ili kontrolni ne utiče značajno na promene u dubini parodontalnih džepova terminima evaluacije.

Učestalost protetskih komplikacija i oštećenja na protezi prikazana je u Tabeli 1. Rezultati su pokazali prelom jednog direktnog retencionog zuba i deformaciju jednog atečmena posle pet 
godina nošenja JKPSP. U poređenju sa podacima nakon sedam dana i prve godine nošenja JKPSP, ovaj rezultat nema statističku značajnost. Broj oštećenja na akrilatnim zubima iz proteze značajno je povećan tokom vremena. Deformacija baze proteze nije uočena ni kod jednog pacijenata uključenog u studiju.

U Tabeli 2 prikazano je zadovoljstvo pacijenata protezama koje uključuje stabilnost i udobnost proteze, kao i poteškoće tokom manipulisanja JKPSP-om. Rezultati su pokazali značajno poboljšanje svih posmatranih parametara nakon prve i pete godine nošenja proteze u poređenju sa podacima merenim sedam dana po predaji proteze. Stabilnost proteze ocenjena je najvišom ocenom tokom celog perioda evaluacije.

\section{DISKUSIJA}

Parcijalno krezubi pacijenti sa skraćenim zubnim nizom najčešće se zbrinjavaju parcijalnim skeletiranim protezama i pored različitih terapijskih rešenja koja su omogućena ugradnjom dentalnih implantata [10]. S tim u vezi, od velikog je značaja uskladiti očuvanje potpornih tkiva (rezidualnog grebena i retencionih zuba) sa estetskim zahtevima i komforom kod nosilaca parcijalnih proteza. Pregledom dostupne literature, mali broj istraživanja pratio je JKPSP $[11,12]$, koja se može smatrati zubnom nadoknadom zadovoljavajućih estetskih i funkcionalnih vrednosti.

Rezultati ove studije su pokazali da su nosioci JKPSP ocenili visokim vrednostima sva tri merena protetska parametra: stabilnost, udobnost i način manipulisanja tokom evaluacije posle sedam dana, prve i pete godine od predaje proteze. Dizajn JKPSP sa odsustvom velike spojnice se može porediti sa krilnim mostovima, koji pokazuju izrazite prednosti u odnosu na klasičnu PSP kada su u pitanju komfor i zadovoljstvo pacijenata [12]. Podatak da je zadovoljstvo pacijenata značajno raslo tokom vremena može se dovesti u vezu sa činjenicom da je period od sedam dana kratak za adaptaciju pacijenata na JKPSP, pa su stoga stabilnost, komfor i manipulacije tokom skidanja i stavljanja proteze bili ocenjeni nižim ocenama. Kako je vreme prolazilo, pacijenti su s lakoćom manipulisali protezom i time je rastao komfor tokom nošenja proteze. Koliko je veliko opterećenje zuba nosača nadoknada, koje u svom sastavu nemaju veliku spojnicu a nose dodate veštačke zube, predstavlja kontroverzno pitanje. Rezultati ove studije ukazali su na frakturu jednog zuba nosača nakon pet godina nošenja JKPSP. Ovaj rezultat je u skladu sa nalazima kliničke petogodišnje studije Schmitta i sar., gde su praćene jednostrane skeletirane proteze retinirane miniatečmenom i klasična PSP sa dvostranim slobodnim sedlom [13]. Rezultati navedenih autora pokazali su značajno veću učestalost fraktura nesplintiranih zuba nosača klasične PSP sa obostranim slobodnim sedlom, nasuprot jednostranoj protezi, gde su splintirani zubi imali duže vreme opstanka. Prikazani rezultati su u skladu i sa nalazima analiza opterećenja JKPSP u studiji koja je koristila metodu konačnih elemenata (MKE) [14]. Na osnovu analize MKE uočeno je da je opterećenje JKPSP-om direktnog i indirektnog retencionog zuba u fiziološkim granicama. Navedeno je u saglasnosti sa opterećenjima koje indukuje konvencionalna PSP na retencione zube.

Rezultati koji se tiču tehničkih komplikacija JKPSP pokazali su reparabilna oštećenja opruge u sastavu atečmena posle pet godina nošenja proteze. Schmitta i sar. [13] pokazali su visoku učestalost mehaničkog trošenja patrice, bez mogućnosti reparacije korišćenog miniatečmena posle četiri godine nošenja proteze. U skladu sa pomenutim, atečmen tipa reze sa oprugom bi mogao biti pouzdanije retenciono sredstvo u odnosu na miniatečmen. Ovo istraživanje je pokazalo i da atečmen tipa reze sa oprugom i dugmetom obezbeđuje dobru stabilnost proteze kod jednostranog slobodnog sedla i bezbedno korišćenje tokom funkcija s obzirom na to da je nemoguće skinuti protezu ukoliko se dugme ne prisne rukom odgovarjućom silom. Nalaz oštećenja na veštačkin zubima predstavlja učestalu komplikaciju u vezi sa JKPSP i dobijeni rezultat je u skladu sa studijom Schmitt i sar. [13].

Imajući u vidu činjenicu da su najčešći razlozi gubitka retencionih zuba karijes i parodontalna oboljenja $[15,16]$, sprovedeno istraživanje je ukjučilo i praćenje parodontoloških parametara. Rezultati su pokazali da su gubitak vertikalnog pripoja gingive i dubina parodontalnih džepova kako na DRZ i IRZ, tako i na KZ, značajno rasli tokom vremena. Međutim, gubitak vertikalnog pripoja gingive i dubina parodontalnih dzepova na DRZ i IRZ nisu se značajno razlikovali od vrednosti na KZ koji nisu bili u sastavu JKPSP. Stoga možemo pretpostaviti da povezivanje zuba nosača povećava otpornost na opterećenje nezavisno od prisustva velike spojnice. Atečmen sa oprugom tipa reze obezbeđuje elastičnu vezu između fiksnog dela i maksimalno ekstendiranog mobilnog dela nadoknade obezbeđujući dobru prognozu retencionim zubima i njihovim potpornim tkivima. U skladu sa navedenim, Jorge i sar. [17] pokazali su da takvi preduslovi treba da budu uključeni u planiranje i dizajn proteza i drugih zubnih nadoknada.

Interesantno je pomenuti da su kliničke studije koje su pratile klasičnu PSP pokazale oprečne nalaze u vezi sa uticajem funkcije zuba (direktni nosač, indirektni, kontrolni zub) na gubitak parodontalnog pripoja. Nasuprot nalazima koji su ukazali na značajan uticaj funkcije zuba na gingivalnu recesiju i dubinu džepova $[18,19]$, rezultati Drake i Beck [20] nisu pokazali razliku u parodontološkom statusu zuba u odnosu na to da li je nošena PSP ili ne. Schmitt i sar. [13] su čak prikazali poboljšanje parodontalnih parametara zuba nosača jednostrane proteze $u$ odnosu na početno stanje, implicirajući da splintiranje zuba i protetska rehabilitacija povoljno utiču na parodontalno zdravlje.

Za bolje i pouzdanije predviđanje kliničkih performansi JKPSP neophodno je uključiti veći broj ispitanika tokom dužeg vremena evaluacije, $s$ obzirom na to da je glavno ograničenje ove studije mali broj uzoraka. Bez obzira na mali broj uzoraka, distribucija rezultata je u skladu sa referentnim studijama [21, 22], i može ukratko prikazati uspešnost terapije JKPSP-om.

\section{ZAKLJUČAK}

Nezavisno od ograničenja ove kliničke studije, uzimajući u obzir adekvatnu indikaciju i pravilno održavanje higijene, JKPSP se može smatrati dobrom opcijom za rehabilitaciju krezubosti Kenedi II klase kod pacijenata kod kojih nije indikovana terapija implantatima, odnosno koji ne prihvataju prisustvo velike spojnice. Pacijenti su bili zadovoljni protezama, njihovim komforom i lakoćom rukovanja. 